Commentary on COVID-19 AND THE Food SyStem

\title{
Economic security assessment of San Jorge, Samar, Philippines, as it experiences coronavirus
}

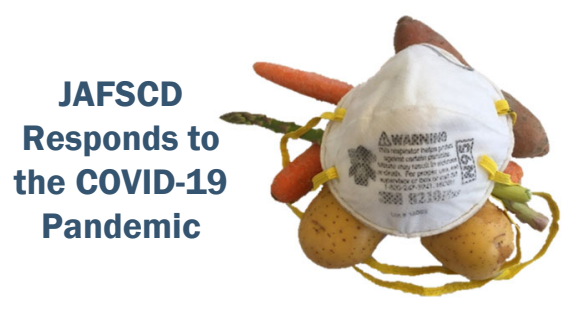

\author{
Marcos E. Bollido * \\ Northwest Samar State University
}

Submitted April 30, 2020 / Published online June 11, 2020

Citation: Bollido, M. E. (2020). Economic security assessment of San Jorge, Samar, Philippines, as it experiences coronavirus. Journal of Agriculture, Food Systems, and

Community Development, 9(4), 131-134. https://doi.org/10.5304/jafscd.2020.094.005

Copyright (C) 2020 by the Author. Published by the Lyson Center for Civic Agriculture and Food Systems. Open access under CC-BY license.

\begin{abstract}
This study assesses the economic security of the city of San Jorge, Samar, Philippines, in terms of livelihood, income, and health in order to analyze the extent of the effect of the novel coronavirus (COVID-19) on the populace. The study evaluates the responses provided by the government, private nongovernmental organizations (NGOs), and international nongovernmental organizations (INGOs). It also looks at how people coped with the crisis during and after the community quarantine. Families received cash and food assistance from local government and other concerned INGOs, which was given to augment the expenses for food, health, and education of their children. The families coped with the food shortage by reducing the number of daily meals and by replacing rice in meals with root crops and vegetables.
\end{abstract}

\section{Introduction}

The community of San Jorge is a 4th class municipality (with an annual income of 10-15 million ${ }^{1}$ ) in the province of Samar, Philippines. According to the 2015 census by the Philippine Statistics Authority (PSA), it has a total of 17,184 in population in 41 villages (PSA, 2015). * Marcos E. Bollido, Northwest Samar State University, Barangay Erenas, San Jorge, Samar, Philippines; +63 9995836494 ;
markbollido@yahoo.com

11 Philippine peso (P1) $=\mathrm{US} \$ 0.02$ as of this writing. 
The town was battered by the COVID-19 pandemic, with a substantial impact on lives and harm to the livelihoods of the population. The agricultural sector had just been recovering from the effects of typhoon Kammuri (or Tisoy) in December 2019. The coconut industry is the primary source of cash income in the area, so the livelihoods of coconut farmers from upland and farm laborers have been affected negatively by the pandemic. For the staple food crop of rice, farmers were affected since they had just planted rice when the typhoon hit (Department of Agriculture, 2019).

\section{Methodology}

I collected secondary data from government offices and conducted an ocular survey, direct observation, focus group discussion, and individual interviews with residents who were affected by the COVID-19 pandemic.

Figure 1. The Philippines and San Jorge, Samar
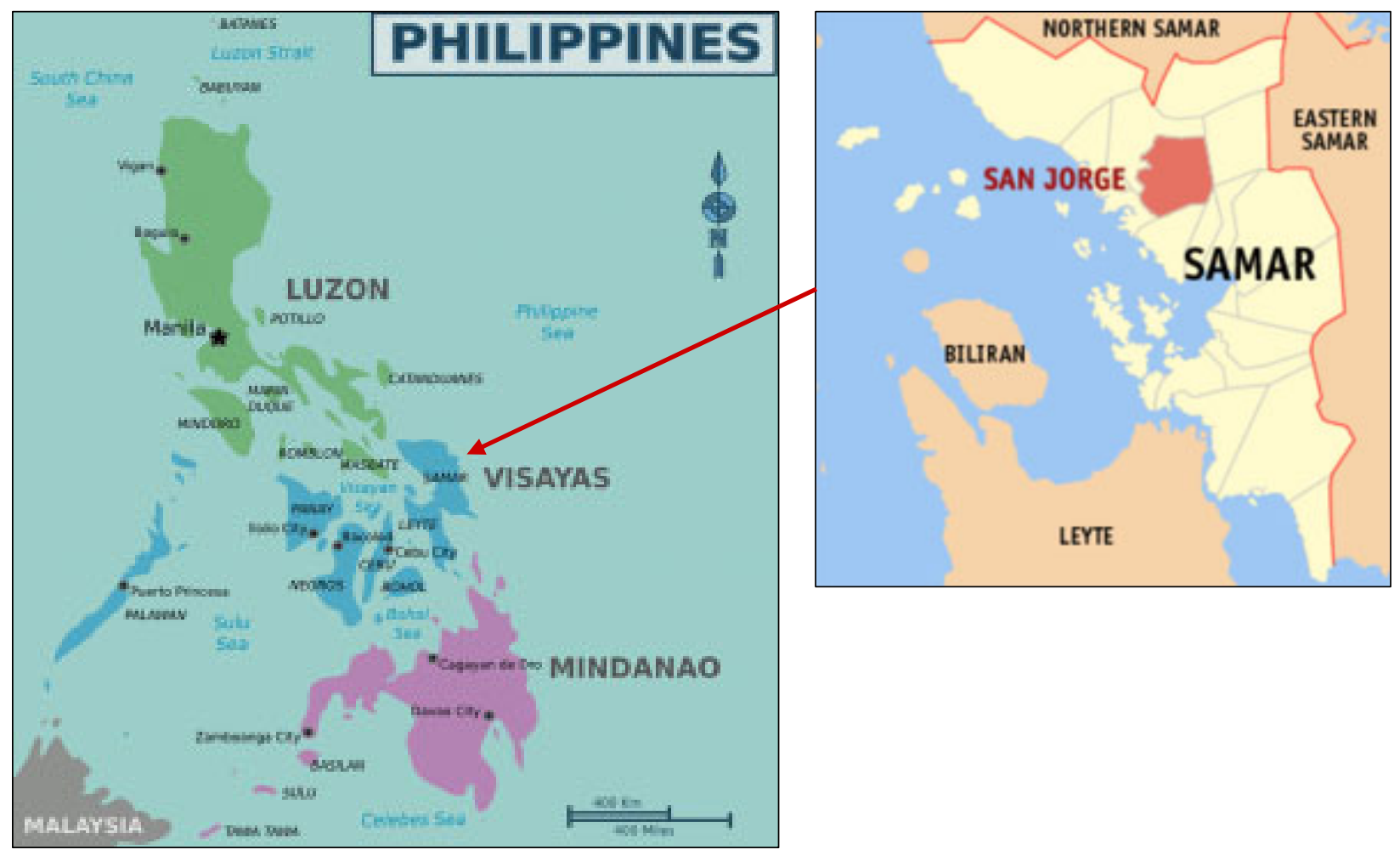

\section{Results}

All residents of San Jorge were affected by the pandemic. Their livelihoods were completely stopped, and this affected their living conditions. Residents received food assistance from local government and concerned NGOs and INGOs. They coped with the food shortage by eating root crops and leafy vegetables and making rice porridge eaten with dried fish. Furthermore, food security was uncertain for families who rely solely on farm labor as their livelihoods. Families who are members of the government's Conditional Cash Transfer received cash grants to improve the health and nutrition of their children and to continue the education of their children. Rice farmers were most affected because they had planted their rice recently when the pandemic occurred, and they were not permitted to visit their farms. 


\section{Coping Strategies}

Through my focus group and individual interviews with residents, I found that the following strategies were used by many residents:

- Reduce the quantity of food served per meal;

- Reduce the number of meals per day (the normal three meals a day dropped to two meals a day);

- Replace rice with root crops and vegetables;

- Borrow money from small sari-sari shops (neighborhood sundry shops) whenever there was no income generated;

- Receive support from Conditional Cash Transfer and food relief;

- Sell assets to have ready cash in case of health emergencies.

\section{Food Consumption}

Food insecurity was experienced in San Jorge communities, especially the poorest sectors. Before the crisis, a family usually ate three times a day. A family of five typically consumes at least two to three kilograms of rice eaten with fish, canned goods, and vegetables, or sometimes other meat on some occasions. During this pandemic, a family usually ate root crops, porridge, dried fish, and vegetables. They tried to extend their food supply by eating twice a day and by eating less, and by substituting rice porridge and sometimes porridge mixed with root crops and dried fish. At times, the adults eat minimally, giving priority to small children.

\section{Food Production}

Food production is diversified; most of the households engage their owned coconut farm. Only 3\% of rice farms are irrigated, which allows for two croppings. The average harvest of rice per hectare is 50 cavans $(5,512 \mathrm{lbs}$. or 2,500 kg) for rainfed and 70 cavans $(7,716 \mathrm{lbs}$. or 3,500 kg) for irrigated. Most farmers also grow root crops, banana, and vegetables as source of food and cash. Villages along the river have been able to harvest freshwater fish and shells. The pandemic has worsened the situation as farmers have not been able to visit their farms to take care of the existing plants or do any additional planting.

\section{Income}

Normally, a coconut farmer who owns 1 hectare of coconut has an average income of P2500/month. Unskilled laborers who work at least 15 days a month earn P3,750 a month, and skilled workers earn P5,000-P6,000 per month. The tenant and owner usually have a 50/50 sharing arrangement for the income, which depends on the volume of production. During this pandemic, most people have been completely dependent on cash assistance.

\section{Nutrition Situation}

Prior to the start of the pandemic, the municipality of San Jorge had a malnutrition prevalence rate of 16.78\% (Republic of the Philippines Department of Health, 2019). The malnutrition prevalence rate was increasing during the pandemic due to decreases in food production and family income to sustain basic food needs. Vulnerable families have difficulty in meeting the recommended 2400 kilocalories per person per day, and this is especially true for large, low-income families.

\section{Access to Functioning Markets and Institutional Services}

The market is still accessible for a family's daily needs from the central market in the town though a representative from every village. There are rural banks in the area and other money-transfer services. 
The government depends mainly on its calamity fund to respond to the immediate needs of affected residents. The Department of Social Welfare and Development immediately provided food and cash, whereas the Department of Agriculture distributed a few packs of vegetable seeds.

\section{Conclusions}

- Farm laborers and farmers who rely solely on coconut production did not expected any income, and their families extended their food supply by limiting their food consumption.

- Food production for the coming season will be insufficient, since people were prohibited from visiting their farms.

- Malnutrition definitely will increase if food consumption drops further.

- Affected families will continue to depend on relief in order to purchase food.

- Children and the elderly will continue to have increased susceptibility to community transmission of COVID-19.

- People should always practice excellent sanitation, wear face masks, and maintain social distancing.

- People should obey the local and national laws and advisories.

\section{References}

Department of Agriculture, ILOCOS Region. (2019, December 3). Typhoon "Tisoy" slightly intensifies while hitting Northern Samar. Retrieved from http://ilocos.da.gov.ph/index.php/17-featured-articles/5358-typhoon-tisoyslightly-intensifies-while-hitting-northern-samar

Philippine Statistics Authority. (2015). 2015 Census of Population: Demographic and socioeconomic characteristics, Samar (Western Samar) (Report No. 2). Philippines. Retrieved from http://www.psa.gov.ph/sites/default/files/08 Samar\%2520\%2528Western\%2520Samar\%2529.pdf

Republic of the Philippines Department of Health. (2019, August 14). LGU Scorecard-Regional summary: LGU Scorecard on Health: LGU Name: San Jorge; Province: Samar (western Samar); Region: Region VIII; DCF Year: 2018 (p. 27). Retrieved from http://ro8.doh.gov.ph/lgu-scorecard/ 